\title{
PEMANFAATAN APLIKASI WHATSAPP SEBAGAI MEDIA PEMBELAJARAN BERBASIS DISTANCE LEARNING
}

\author{
M. Anas Hidayat ${ }^{1}$, Ahmad Faiz Mahbubi Addaraini², \\ M. Redho Rahman³, Danial Hilmi4 \\ ${ }^{1}$ Pascasarjana UIN Maulana Malik Ibrahim Malang, Indonesia \\ ${ }^{2}$ Pascasarjana UIN Maulana Malik Ibrahim Malang, Indonesia \\ ${ }^{3}$ Pascasarjana UIN Maulana Malik Ibrahim Malang, Indonesia \\ ${ }^{4}$ Pascasarjana UIN Maulana Malik Ibrahim Malang, Indonesia \\ Email:ahmadfaizma376@gmail.com ${ }^{1}$,denmasanas45@gmail.com, ${ }^{2}$ \\ redhorahman@gmail.com,33ilmi@pba.uin-malang.ac.id, ${ }^{4}$
}

\begin{tabular}{c|c|c}
\hline Received: Juni 2021 & Accepted: Juli 2021 & Published: Juli 2021 \\
\hline
\end{tabular}

\begin{abstract}
The Whatsapp (WA) application has become the most popular social media in the world which was started due to features that are easy and flexible to use for daily communication. One very useful feature is the group chat feature, where users can create private groups and can be devoted to anything, including educational purposes. With its advantages, Whatsapp has become widely used as a learning medium. The purpose of this study is to describe the use of the Whatsapp application in distance learning-based learning and the researcher uses class E MPBA UIN Malang as the object of this research. The type of this research is descriptive qualitative research. The results of this study describe first, the implementation of the use of Whasapp as a learning medium, second, the obstacles to using the Whatsapp application in distance learning-based learning in class E MPBA UIN Malang, and third, the solution for using Whatsapp applications in distance learning-based learning in class E MPBA UIN Malang.
\end{abstract}

Keywords: Social Media, Distance learning, Whatsapp

\begin{abstract}
Abstrak: Aplikasi Whatsapp (WA) menjadi media sosial paling populer di seluruh dunia yang dimulai disebabkan pada fitur-fitur yang mudah dan fleksibel untuk digunakan berkomunikasi sehari-hari. Salah satu fitur yang sangat berguna adalah fitur grup chatting, di mana pengguna bisa membuat grup secara pribadi dan bisa dikhususkan untuk apa saja, termasuk untuk kepentingan pendidikan. Dengan kelebihannya, Whatsapp menjadi banyak digunakan sebagai media pembelajaran. Maksud dari penelitian ini ialah mendekskripsikan pemanfaatan aplikasi Whatsapp dalam pembelajaran berbasis distance learning dan peneliti menggunakan kelas $E$ MPBA UIN Malang sebagai objek penelitian ini. Adapun jenis penelitian ini adalah penelitian kualitatif deskriptif. Hasil penelitian ini mendekskripsikan pertama, pelaksanaan pemanfaatan Whasapp sebagai media pembelajaran, kedua, kendala pemanfaatan aplikasi Whatsapp dalam pembelajaran berbasis distance learning di kelas E MPBA UIN Malang, dan ketiga, solusi pemanfaatan aplikasi Whatsapp dalam pembelajaran berbasis distance learning di kelas $E$ MPBA UIN Malang.
\end{abstract}

Kata Kunci: Media sosial, Distance learning, Whatsapp 


\section{A. Pendahuluan}

Saat ini dunia sedang mengalami transformasi dari zaman klasik ke zaman modern yang diiringi dengan kemajuan teknologi yang memudahkan perpindahan atau transfer kegiatan individu atau kelompok sehari-hari. Perubahan dunia yang sangat cepat ini pada akhirnya disebut dengan era globalisasi dimana teknologi menjadi kebutuhan utama manusia dalam menjalankan aktivitasnya. Teknologi bukan hanya membantu manusia didunia nyata akan tetapi ia seakan membuat dunia baru dimana manusia banyak sekali menjalankan aktifitas di dalamnya. Dunia ini pada akhirnya disebut dengan dunia maya atau dunia internet. Dunia internet tidak memiliki batasan ruang sehingga untuk mengaksesnya diperlukan komputer atau alat elektronik yang bisa mengakses internet seperti ponsel pintar dan laptop. Kecanggihan dunia internet ini, ditandai dengan semakin cepatnya transfer informasi dari suatu tempat ke tempat lain hanya dengan hitungan detik. Dengan munculnya dunia internet ini, sosialisasi manusia berubah secara drastic. Mereka tidak perlu lagi bertemu langsung untuk berkomunikasi akan tetapi menggunakan dunia internet dan terhubung secara virtual dengan tanpa batasan ruang dan waktu. Media dalam dunia internet yang sering digunakan manusia untuk berkomunikasi ini disebut dengan media sosial.

Menurut data terbaru dari Hootsuite, pengguna internet aktif didunia saat ini mencapai 4,66 Miliar dan pengguna media sosial mencapai 4,2 Miliar dari 7,88 Miliar penduduk dunia. ${ }^{1}$ Data ini menunjukkan bahwa lebih dari separuh penduduk dunia saat ini mengakses internet dan bermedia sosial. Adapun macam-macam media sosial paling populer di dunia adalah facebook, instagram, twitter, dan whatsapp. Dari keempat media sosial tersebut, Whatsapp adalah media sosial yang paling banyak digunakan manusia dengan jumlah pengguna mencapa 2 Miliar. ${ }^{2}$ Dari data pengguna Whatsapp tersebut, bisa disimpulkan bahwa Whatsapp adalah media sosial yang paling populer sehingga media ini terkadang digunakan bukan hanya untuk sekedar hiburan akan tetapi media untuk saling bertukar informasi dalam segala aspek, baik aspek yang kurang fundamental, seperti aspek hiburan ataupun aspek yang sangat fundamental seperti aspek pendidikan.

Dalam pendidikan, pembelajaran yang berlangsung secara virtual disebut dengan distance learning dengan menggunakan media pembelajaran yang dibuat khusus untuk distance learning, seperti aplikasi Rumah Belajar, Ruangguru, Quipper, dan masih banyak lagi. Akan tetapi sebagian besar instansi pendidikan menggunakan aplikasi Whatsapp sebagai media pembelajaran meskipun aplikasi tersebut bukan dibuat khusus untuk pembelajaran. Hal ini didukung dengan data dari LPMP Jatim (Lembaga Penjamin Mutu Pendidikan Jawa Timur) yang menunjukkan bahwa aplikasi

1 Liputan6.com, "Pengguna Internet Dunia Tembus 4,66 Miliar, Rata-Rata Online di Smartphone," liputan6.com, 28 Januari 2021, https://www.liputan6.com/tekno/read/4469008/pengguna-internet-duniatembus-466-miliar-rata-rata-online-di-smartphone.

2 Kompas, “Whatsapp Tembus 2 Miliar Pengguna," diakses 3 Juli 2021, https://tekno.kompas.com/read/2020/02/13/18190017/whatsapp-tembus-2-miliar-pengguna. 
Whatsapp adalah media sosial paling populer di kalangan pengajar, pemerhati pendidikan, dan guru dalam pembelajaran jarak jauh atau distance learning dengan indeks persentase penggunaan mencapai $28,14 \%$, disusul dengan indeks persentase penggunaan media pembelajaran Rumah Belajar 20,78 \%, dan Ruang Guru 5,12 \% ${ }^{3}$

Inilah urgensi dari penelitian ini bahwa media sosial Whatsapp saat ini sangat penting dijadikan media alternatif dalam dunia pembelajaran karena merupakan media sosial paling popular dan berhasil mengalahkan media pembelajaran lainnya yang ada di Indonesia. Adapun penelitian mengenai pemanfaatan Whatsapp sebagai media pembelajaran daring sudah banyak dilakukan, salah satunya adalah skripsi yang ditulis oleh Wiji Lestari dan Andika Prajana. Lestari menuliskan tujuan skripsinya tersebut tentang pemanfaatan whatsapp sebagai media pembelajaran daring pada masa pandemi covid-19 di kelas VI SDN 6 Kota Jambi,, ${ }^{4}$ sedangkan tujuan penelitian yang dilakukan oleh Prajana adalah untuk memanfaatkan aplikasi Whatsapp semaksimal mungkin dengan diintegrasikan dalam sistem pembelajaran E-learning kampus. Adapun rumusan masalah yang dibahas dalam penelitiannya adalah pertama, bagaimana implementasi aplikasi Whatsapp untuk media pembelajaran daring, dan kedua, bagaimana pengelolaan aplikasi Whatsapp untuk media pembelajaran pada sistem E-learning kampus. ${ }^{5}$ Dari kedua penelitian diatas, bisa ditarik kesimpulan tentang persamaan dan perbandingan dengan kedua penelitian diatas dengan penelitian ini. Adapun persamaannya adalah tentang pemanfaatan Whatsapp sebagai media pembelajaran, namun perbedaannya adalah objek penelitian yang dipakai. Penelitian yang ditulis oleh Lestari menggunakan objek siswa kelas VI Sekolah Dasar, dan penelitian yang ditulis oleh Prajana menggunakan objek sistem E-learning kampus UIN Ar-Raniry. Sedangkan penelitian ini menggunakan objek mahasiswa pascasarjana PBA UIN Malang.

Oleh karena itu, tujuan dari penelitian ini adalah untuk mendeskripsikan pemanfaatan aplikasi Whatsapp dalam pembelajaran daring atau distance learning dan peneliti menggunakan kelas E MPBA UIN Malang sebagai objek penelitian ini. Maka rumusan masalah yang akan dibahas dalam penelitian ini adalah pertama, pelaksanaan pemanfaatan Whatsapp sebagai media pembelajaran; kedua, kendala aplikasi Whatsapp sebagai media pembelajaran berbasis daring pada kelas E MPBA UIN Malang; dan ketiga, solusi pemanfaatan aplikasi Whatsapp sebagai media pembelajaran berbasis daring pada kelas E MPBA UIN Malang.

3 LPMP Jatim, “Whatsapp Paling Diminati untuk Pembelajaran Online,” diakses 3 Juli 2021, https://lpmpjatim.kemdikbud.go.id/site/detailpost/whatsapp-paling-diminati-untuk-pembelajaran-online.

4 Wiji Lestari, "Pemanfaatan Whatsapp Sebagai Media Pembelajaran Dalam Jaringan Masa Pandemi Covid-19 Di Kelas Vi Sekolah Dasar" (Skripsi, Universitas Jambi, 2021).

5 Andika Prajana, "Pemanfaatan aplikasi whatsapp untuk media pembelajaran dalam lingkungan uin ar-raniry Banda Aceh," Cyberspace: Jurnal Pendidikan Teknologi Informasi 1, no. 2 (2017): 124. 


\section{B. Kajian Teori}

\section{Pengertian Distance learning}

Daniel (1999), berpendapat bahwa distance learning adalah suatu program pembelajaran yang bersifat alternatif karena tidak adanya pertemuan langsung antara guru dan murid sehingga menurunkan intensitas pengawasan dan pendampingan guru terhadap murid dan meletakkan kesuksesan pembelajaran kepada kemauan dan kemampuan masing-masing murid. ${ }^{6}$ Sukamto, dkk (2004) berpendapat bahwa distance learning adalah pembelajaran jarak jauh antara guru dan murid sehingga kesuksesan pembelajaran terletak pada kemampuan masing-masing dalam penggunaan teknologi dan media informasi. Distance learning adalah ekosistem belajar yang lengkap dan baru karena fleksibel terhadap waktu dan tempat sehingga lebih cocok diterapkan pada pembelajar dewasa, seperti mahasiswa. Dari pendapat para ahli diatas, dapat disimpulkan bahwa distance learning adalah pembelajaran jarak jauh yang dilaksanakan menggunakan teknologi dan media informasi sehingga guru dan murid bisa terhubung secara virtual dalam menyampaikan materi pembelajaran.

Adapun karakteristik dari distance learning adalah sebagai berikut; 7 pertama, tidak memiliki batasan tempat, kedua, tidak memiliki batasan waktu, ketiga, sumber belajar disediakan oleh guru dan disampaikan secara virtual atau daring, keempat, biasa melakukan pertemuan tatap muka secara virtual atau daring dengan menggunakan fitur video call, kelima, jadwal pembelajaran bisa diatur oleh guru, keenam, bertujuan untuk meningkatkan pengetahuan, ketrampilan, dan sikap peserta didik, ketujuh, menjangkau semua jenjang pendidikan dari tingkat dasar sampai mahasiswa, dan kedelapan, kesuksesan peserta didik tergantung kemauan dan kemampuan individu karena keterbatasan guru dalam mendampingi.

\section{Pengertian Aplikasi Whatsapp}

Whatsapp adalah aplikasi untuk mengirim pesan antar penggunanya yang berupa tulisan, gembar, suara, dan video dengan menggunakan ponsel pintar. Dikarenakan Whatsapp adalah aplikasi yang terdapat pada ponsel pintar, maka untuk mengaksesnya diperlukan paket data internet sehingga tidak lagi menggunakan biaya provider SMS. Proses pengiriman pesan antar pengguna dalam aplikasi ini disebut dengan chatting. Adapun fitur yang sangat bermanfaat dan membedakannya dengan aplikasi sosial online lainnya, adalah fitur grup. Dengan fitur ini, orang bisa membuat grup khusus sesuai kehendaknya sehingga bisa dijadikan tempat berkumpul online berbagai macam komunitas, keluarga, organisasi, dan lain-lain. Kapasitas fitur grup ini terbatas

${ }^{6}$ Sri Anitah, Media pembelajaran (Surakarta: UPT UNS Press Universitas Sebelas Maret, 2008), 110.

${ }^{7}$ Munir, Kurikulum Berbasis Teknologi Informasi dan Komunikasi (Bandung: Alfabeta, t.t.), 218. 
hanya untuk maksimal 250 pengguna yang bisa masuk dalam satu grup. Namun dari keterbatasan itu, membuat fitur grup ini sangat efektif dalam percakapan sehari-hari karena jika tidak memiliki batasan, akan membuat grup ini menjadi tidak efektif dalam percakapan sehari-hari. Selain kelebihan dalam fiturnya, Whatsapp juga memiliki kelebihan dengan ukurannya yang kecil sehingga aplikasi ini cukup ringan dan dijadikan media sosial utama pada ponsel pintar. Hal inilah yang membuat aplikasi ini menjadi media sosial yang paling banyak digunakan didunia. ${ }^{8}$

Dalam sejarah berdirinya, Whatsapp berasal dari kata "what's up" yang berarti apa kabar. Whatsapp didirikan oleh Brian Acton dan Jan Koum pada tanggal 24 Februari 2009. Meskipun saat itu keduanya masih bekerja sebagai karyawan di perusahaan teknologi informasi Yahoo, mereka bisa merintis versi pertamanya dan diaplikasi pada komunitas Rusia mereka. Pada awalnya, aplikasi ini hanya bisa untuk update status pengguna untuk para orang-orang komunitas Rusia tersebut, dan fitur chatting baru muncul pada rilisan Whatsapp versi 2.0 atau versi kedua. Tak lama setelah perilisan Whatsapp versi kedua tersebut, pengguna aplikasi ini melejit hingga mencapai 250 ribu orang dan akhirnya Brian Acton dan Jan Koum mulai mengembangkan aplikasi ini secara serius dengan membuka start-up baru dan bekerja sama dengan pihak lain.

Dalam perkembangannya, aplikasi ini tercatat menjadi aplikasi dengan lonjakan pengguna paling drastis dibandingkan dengan aplikasi lain yang serupa. Pada tahun 2014 saja, pendapatannya mencapai 19 miliar dollar AS dan popularitasnya mengalahkan facebook yang sebelumnya menjadi aplikasi media sosial paling populer di dunia. Tahun 2014 juga disebut sebagai tahun kesuksesan terbesar bagi aplikasi whatsapp karena dalam satu tahun jumlah pengguna baru mencapai 700 juta pengguna dan pada tahun 2015 naik menjadi 900 juta pengguna. ${ }^{9}$ Disamping kelebihan aplikasi Whatsapp yang disinggung sedikit sebelumnya, berikut fitur lengkap dari aplikasi Whatsapp tersebut; pertama, dapat mengirim sebuah pesan berupa teks, suara, foto, dan video dari galeri atau kamera beserta dokumen lainnya yang biasa memiliki format pdf, word, atau sejenisnya atau fitur ini biasa disebut dengan chatting. Kedua, menelpon melalui suara dan gambar atau fitur ini biasa disebut dengan video call. Ketiga, berbagi lokasi pengguna dengan GPS atau fitur ini biasa disebut dengan sherlock. Keempat, mendukung beberapa emoji yang minimalis. Emoji disini adalah gambar kartun wajah yang bisa mengekspresikan perasaan yang sedang dialami oleh pengguna. Kelima, mengirim kontak telepon, dan keenam, pengguna bisa mengatur profilnya sendiri, yang berisi nama, foto, dan status pengguna, serta bisa melindungi privasi pengguna atau fitur ini biasa disebut dengan status privacy. Itulah beberapa kelebihan dan fitur-fitur dari aplikasi Whatsapp yang sangat popular.

\footnotetext{
${ }^{8}$ Rani Suryani, "Fungsi Whatsapp Grup Shalihah Cabang Bandar Lampung Sebagai Pengembangan Media Dakwah Dalam Membentuk Akhlakul Karimah” (UIN Raden Intan Lampung, 2017), 18.

${ }^{9}$ Suryani, 20.
} 


\section{Metode Penelitian}

Adapun metode yang peneliti gunakan dalam penelitian ini menggunakan pendekatan deskriptif kualitatif. Dalam penelitian ini, pengumpulan data dilakukan melalui tiga teknik: wawancara, dokumentasi dan observasi. Adapun teknik pengolahan data pada penelitian ini yaitu dengan cara reduksi, penyajian data, dan penarikan kesimpulan. Reduksi yaitu dilakukan dengan cara merangkum, memilih hal-hal pokok. Kemudian peneliti menyajikan data tersebut dalam bentuk naratif dengan terlebih dahulu mengelompokkan berdasarkan sub-sub masing-masing. Dan terakhir membuat kesimpulan dari penelitian. Untuk menjaga keabsahan data, dilakukan triangulasi. Triangulasi yang dimaksud adalah dengan menggunakan sumber dengan cara mengecek data yang diperoleh melalui beberapa sumber terkait.

\section{Hasil dan Pembahasan}

\section{Pelaksanaan Pemanfaatan Whatsapp Sebagai Media Pembelajaran}

Mewabahnya Coronavirus Disease 2019 (Covid-19), dunia sangat dihebohkan dengan peristiwa virus tersebut. Mulanya terjadi di kota Wuhan.,di provinsi Hubei China. Virus corona menular begitu cepat hamparan daratan negeri China bahkan ke seluruh alam kehidupan, tepatnya di Indonesia dan negara lainnya. World Health Organization (WHO) memberi tanggapan atas masalah wabah Covid 2019 dengan keadaan yang darurat dalam kesehatan bahkan acapkali populer dengan Public Health Emergency of International Concern yang terjadi tepat pada 30 Januari 2020. Mirip negara lainnya yang tertular karena wabah tersebut, oleh sebab itu pemerintah negara Indonesia memberikan ketentuan terhadap seluruh masyarakat membuat larangan tidak keluar dari rumah agar tetap menjaga kesehatan dirinya. Kendatipun seluruh kegiatan yang berinteraksi diluar rumah dan berkerumunan misalnya lembaga pendidikan, dianjurkan tidak melaksnakan kegiatan sekolah secara tatap muka, melainkan secara pembelajaran daring (dalam jaringan) atau online, karena metode inilah yang harus dipilih agar kegiatan sekolah tetap berjalan sesuai kondisi meskipun tidak sepenuhnya sama seperti sedia kala.10

Aturan sosial distance sebagai langkah pencegahan supaya virus Covid 2019 tidak menular secara menyeluruh ke berbagai daerah. Social distancing memaksa berbagai pihak untuk merubah pola komunikasi sehari-hari mereka dari bertatap langsung menjadi bertatap secara online dengan menggunakan media sosial. Segala pekerjaan juga berubah menjadi work from home (WTF) atau bekerja dari rumah. Banyak media informasi berbasis teknologi akhirnya populer digunakan untuk mendukung segala pekerjaan berbasis rumah ini. Salah satu penerapan pekerjaan berbasis

\footnotetext{
${ }^{10}$ Ridwan Sanjaya, Refleksi Pembelajaran Daring di Masa Darurat (Semarang: SCU Knowledge Media,
} 2020), 21. 
distance learning ini adalah pendidikan yang dilakukan secara online. Penelitian ini membahas penerapan tersebut dengan mengambil pendekatan fenomenologi karena menggunakan fenomena pembelajaran daring yang terjadi pada mahasiswa Mahasiswa Pascasarjana Prodi Pendidikan Bahasa Arab di UIN Malang. Penerapan pembelajaran daring berbasis Aplikasi Whatsapp ini, jika tidak diimbangi dengan strategi yang digunakan dosen, maka pembelajaran tersebut tidak akan tercapai. Peran mahasiswa di sini sangat diperlukan untuk membantu dosen dalam mengikuti pembelajaran daring untuk bisa saling berinovatif serta tetap konsisten dalam melaksanakan proses pembelajaran saat pandemi Covid-19 ini. Hasil penelitian menyatakan bahwa proses pembelajaran daring yang dilakukan oleh sebagian dosen Prodi Pendidikan Bahasa Arab terutama untuk kelas E menggunakan aplikasi Whatsapp.

Hasil penelitian yang telah dilakukan peneliti dalam Pemanfaatan aplikasi whatsapp sebagai media pembelajaran berbasis distancing learning pada kelas E MPBA UIN Malang disimpulkan bahwa sebagai sarana pembelajaran ini termasuk dalam kategori efektif atau maksimum. Group Mahasiswa M.PBA UIN 2020 merupakan Whatsapp Group yang mampu membangun sebuah pembelajaran yang informatif, menyenangkan dan interaktif terkait berbagai topik atau diskusi tentang kegiatan kemahasiswaan yang berbasis aplikasi Whatsapp sosial media. Sosial media merupakan aplikasi berbasis internet yang memungkinkan setiap penggunanya dapat saling berbagi berbagai macam konten sesuai dengan fitur pendukungnya. Whatsapp Messenger merupakan teknologi popular yang sangat potensial untuk dimanfaatkan sebagai alat pembelajaran.

Dalam keadaan pandemi saat ini, penggunaan media pembelajaran dalam jaringan tentu memberikan kemudahan kepada guru maupun peserta didik dalam proses komunikasi selama melakukan pembelajaran daring. Ada banyak teknologi aplikasi digital yang bisa digunakan Whatsapp merupakan aplikasi berbasis internet yang memudahkan penggunanya dalam berkomunikasi dengan fitur-fitur yang tersedia serta merupakan media sosial yang paling populer digunakan dalam berkomunikasi. Whatsapp menjadi pilihan untuk digunakan menjadi media kedua dalam proses pembelajaran daring bagi Mahasiswa Pascasarjana Prodi Pendidikan Bahasa Arab UIN Maulana Malik Ibrahim Malang. Banyak hasil penelitian lain juga mengatakan bahwa aplikasi Whatsapp adalah media sosial yang dapat dijadikan media pembelajaran yang efektif jika para guru mengetahui mendalam fitur-fitur yang dikandungnya dan dengan memanfaatkan pembelajaran distance learning yang dikenal tidak memiliki batasan ruang dan waktu. ${ }^{11}$

Namun demikian, di tengah situasi yang sangat darurat saat ini, evaluasi dan implementasi pembelajaran daring harus tetap dilakukan guna memastikan proses pembelajaran sesuai dengan

11 Prajana, "Pemanfaatan aplikasi whatsapp untuk media pembelajaran dalam lingkungan uin arraniry Banda Aceh,” 122-23. 
yang diharapkan dan berjalan optimal. Tidak hanya kesiapan jaringan dan yang lainnya, tetapi kesiapan dan kemampuan mengoperasikan teknologi baik dosen dan Mahasiswa. Pembelajaran daring mungkin terasa tidak se-ideal seperti pembelajaran tatap muka secara fisik. Meskipun demikian, dosen berupaya keras mewujudkan capaian pembelajaran melalui pembelajaran daring.

\section{Kendala-kendala dalam Penggunaan Whatsapp Group dalam Proses Pembelajaran di Era Pandemi}

Dalam hal ini peneliti melakukan wawancara untuk mengetahui sejauh mana perkembangan proses pembelajaran di era pandemi ini dengan menggunakan Whatsapp sebagai media pembelajaran berbasis distancing learning kepada semua Mahasiswa Pascasarjana Prodi Pendidikan Bahasa Arab kelas E yaitu terdiri dari 12 orang informan. Wawancara dilakukan dengan cara Chatting secara bergiliran dan disesuaikan dengan waktu ketersediaan Mahasiswa untuk melakukan wawancara secara online. Berdasarkan hasil wawancara bersama 12 informan, didapatkan bahwa hal pertama yang ditanyakan adalah media pembelajaran apa saja yang digunakan yaitu menggunakan media pembelajaran berbasis TIK dengan berbantuan jaringan internet seperti penggunaan E-learning, Whatsapp, Zoom, dan Google Meet dan intensitas penggunaan media yang sering digunakan adalah Whatsapp. Hal ini sesuai dengan kesimpulan wawancara peneliti bersama mahasiswa pada tanggal 27 Mei 2021, bahwa:

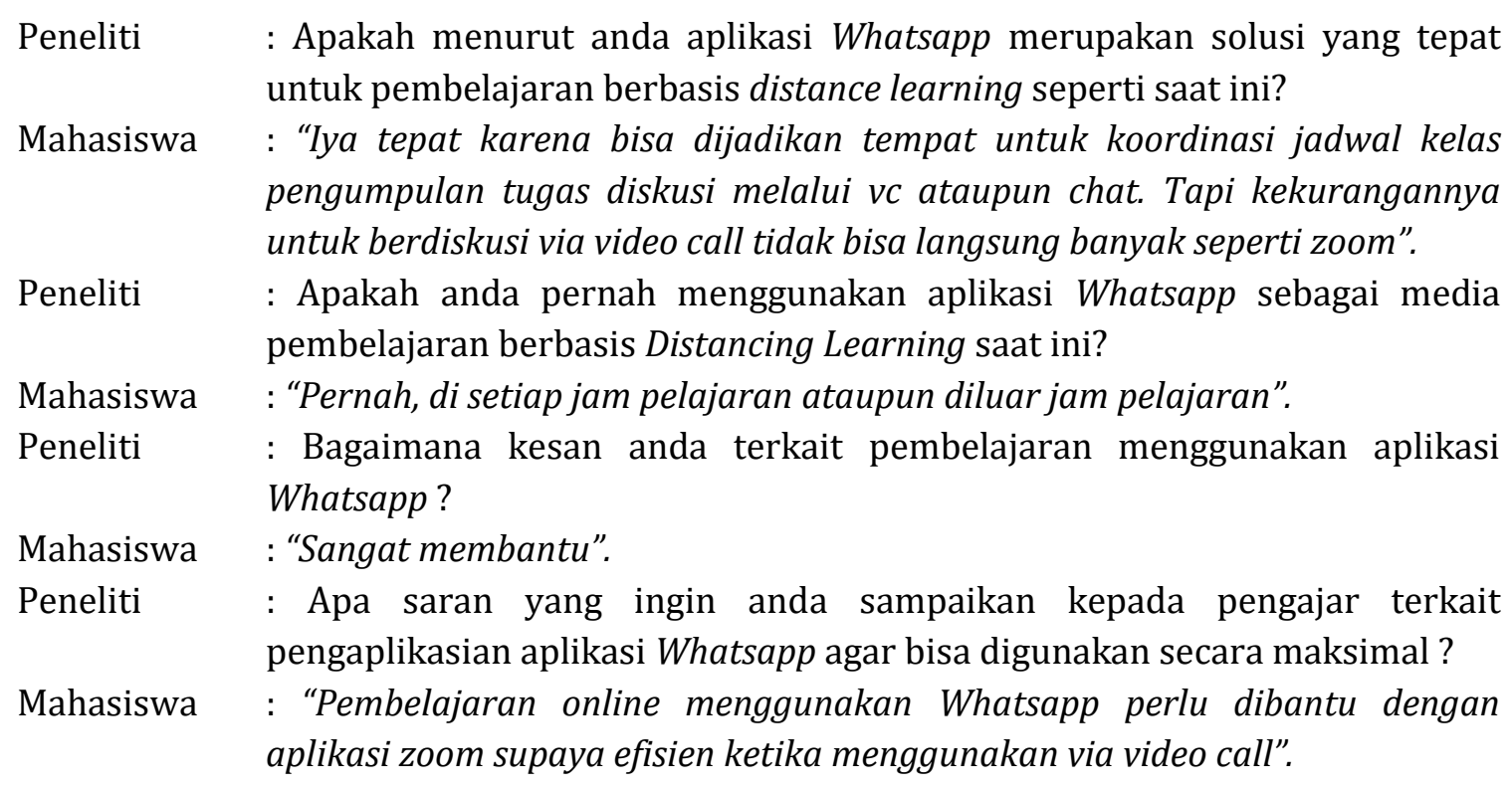

Dari empat pertanyaan di atas dapat disimpulkan dari jawaban 12 orang informan bahwa kendala-kendala dalam penggunaan Whatsapp dalam proses pembelajaran pada masa pandemi yang dialami mahasiswa MPBA semeter 2 kelas E seperti halnya kekurangan Whatsapp yaitu :

a. Tidak ada interaksi langsung antara dosen dan mahasiswa dalam proses pembelajaran apabila dosen hanya menggunakan Whatsapp dalam pembelajaran tanpa media lain untuk interaksi 
langsung seperti melalui zoom, dan google meet untuk memfasilitasi fitur video call. Dalam hal ini jelas bahwa kendala dari aplikasi Whatsapp yaitu keterbatasan anggota saat melakukan video call.

b. Pembelajaran tidak kondusif dan efektif saat diskusi. Sebagian dari mahasiswa yang tidak peduli dengan forum diskusi di Whatsapp karena kurangnya pemantauan dari dosen. Sehingga mahasiswa ataupun dosen tidak mengetahui apakah dari salah satu mereka mengikuti diskusi secara masif atau pasif.

c. Kendala jaringan yang kurang stabil. Terkadang terjadi ketika pembelajaran berlangsung salah satu dari mahasiswa mengalami overload karena gangguan sinyal, ini terjadi karena keterlambatan saat dosen melakukan absensi.

Selanjutnya, manfaat yang dirasakan dalam memanfaatkan whatsapp, terutama dalam proses pembelajaran, didapatkan bahwa Mahasiswa terbantu dengan adanya whatsapp memudahkan dalam berkomunikasi dan berbagi informasi walaupun tidak bisa bertatap muka secara langsung selama pembelajaran online ini.

Mengenai hambatan atau kesulitan yang dirasakan dalam menggunakan whatsapp selama proses pembelajaran daring, didapatkan bahwa Mahasiswa mengalami kesulitan dalam memahami materi, interaksi yang kurang, memori handphone yang penuh dengan semua berkas yang masuk di group whatsapp, terbatasnya saat video call, dan tidak jarang gangguan sinyal yang naik turun.

\section{Solusi untuk Memaksimalkan Penggunaan Whatsapp Group sebagai Inovasi Teknologi Pembelajaran Berbasis Distancing Learning}

Setelah melakukan wawancara, peneliti mendapatkan fakta bahwa pembelajaran berbasis distance learning dengan memanfaatkan aplikasi Whatsapp itu tidak berjalan dengan baik dan tidak mendapatkan hasil yang memuaskan bagi Mahasiswa Pascasarjana Prodi Pendidikan Bahasa Arab. Hal ini dikarenakan para mahasiswa hanya menggunakan ponsel pintar mereka yang terkoneksi dengan internet untuk menyerap semua materi-materi yang cukup berat dari dosen. Materi-materi berat tersebut biasanya menjadi mudah jika disampaikan atau dipraktekan langsung di dalam kelas. Namun, dengan hanya bermodalkan ponsel, mahasiswa tidak memiliki ruang gerak yang cukup luas untuk mengeksplor materi dengan cara bertemu langsung dengan para ahli atau dosen sekitar seperti yang dilakukan dalam pembelajaran langsung di kampus.

Setelah mengetahui kendala-kendala dalam penggunaan Whatsapp dalam proses pembelajaran pada masa pandemi, peneliti memberikan solusi untuk memaksimalkan penggunaan Whatsapp. Solusi-solusi ini diperoleh dari hasil wawancara kepada mahasiswa Pascasarjana Pendidikan Bahasa Arab kelas E. berikut pertanyaan dan jawaban yang diperoleh peneliti : 
Apa saran yang ingin anda sampaikan kepada pengajar terkait pengaplikasian aplikasi Whatsapp agar bisa digunakan secara maksimal ? Dari 12 mahasiswa dapat disimpulkan oleh peneliti, hendaknya Whatsapp bukan menjadi satu-satunya teknologi pembelajaran yang digunakan untuk penyampaian materi, diskusi dalam proses belajar mengajar di era pandemi. Perlu adanya keaktifan dosen dan mahasiswa dalam forum virtual seperti zoom, goole meet atau video call atau video youtube. Agar pesan yang akan akan disampaikan dosen tersampaikan dengan baik, dapat dipahami, pembelajaran menjadi kondusif secara tatap muka melalui virtual, karena pembelajaran dalam jaringan menggunakan Whatsapp perlu dibantu dengan aplikasi zoom, ataupun google meet supaya efisien ketika menggunakan via video call karena pada kedua aplikasi tersebut tidak tertentu batas anggota yang ikut serta dalam mengikuti pembelajaran.

Rusman \& Riyana ${ }^{12}$ mengatakan bahwa anak-anak dapat termotivasi dengan penggunaan media saat pembelajaran berlangsung baik itu dikelas maupun secara daring. Namun pendapat ini tidaklah berbanding lurus dengan apa yang terjadi sebenarnya di lapangan. Banyak kasus yang menyatakan bahwa penggunaan media pembelajaran malah membuat peserta didik tidak fokus dengan materi yang diajarkan bahkan banyak dari mereka bercanda saat proses belajar mengajar berlangsung. Fakta yang didapat oleh peneliti saat wawancara menunjukkan bahwa media pembelajaran membuat semangat mahasiswa menurun yang disebabkan oleh penggunaan media aplikasi Whatsapp. Untuk mengatasi masalah ini, dianjurkan kepada para dosen untuk mengembangkan kreatifitas seluas mungkin dalam penggunaan aplikasi Whatsapp ini dalam pembelajaran. Kekreatifitasan itu bisa diwujudkan dengan berbagai cara, salah satunya adalah dengan menerapkan berbagai macam metode pengajaran yang digabungkan dengan aplikasi Whatsapp. Salah satu contohnya adalah menggunakan metode komunikatif atau metode langsung dalam diskusi antara mahasiswa di mana dosen memberikan aturan dengan mewajibkan mahasiswa untuk menggunakan fitur voice note secara bergiliran dalam menyampaikan pendapat dan bukan hanya melalui fitur chatting.

Para dosen juga dituntut untuk mengetahui keadaan mayoritas mahasiswa untuk bisa menyesuaikan metode yang dipakai hingga ia berjalan efektif dalam pembelajaran daring. Dengan mengetahui keadaan mayoritas mahasiswa, para dosen juga bisa menyesuaikan bentuk materinya dan penyampaiannya sehingga kembali dapat memberikan semangat kepada para mahasiswa untuk belajar secara daring. Penyesuaian-penyesuaian tersebut tentu saja dengan mempertimbangkan fitur-fitur yang ada pada aplikasi Whatsapp, seperti video call atau chat personal.

12 Deni Kurniawan Rusman dan Cepi Riyana, "Pembelajaran Berbasis Teknologi Informasi dan Komunikasi," Bandung: Rajawali Pers, 2011. 
Adapun solusi yang dilakukan oleh para dosen UIN Malang terhadap mahasiswa MPBA UIN Malang kelas E dalam pembelajaran berbasis distance learning adalah dengan meminimalisir akibat buruk yang disebabkan oleh jaringan internet yang tidak stabil. Salah satu caranya adalah dengan memberikan tenggat waktu lebih lama dari deadline yang disepakati dalam mengumpulkan tugas kepada para mahasiswa yang mengalami gangguan sinyal di daerahnya. Seperti yang dikatakan oleh salah satu mahasiswa dari hasil wawancara bahwa ia mengaku tidak bisa setiap hari mengakses internet karena berada diwilayah paling timur Indonesia, yaitu pulau Papua. Selain memberikan tenggat waktu lebih lama, para dosen biasanya memperpendek waktu jam kuliah dari biasanya dengan cara meringkas materinya dan menyederhanakannya hingga mudah dimengerti dengan tanpa waktu yang lama jika banyak sekali mahasiswa yang sedang mengalami gagal sinyal. Disisi lain, para dosen menggunakan media pendukung seperti google meet atau zoom meeting dalam berinovasi dengan tidak melupakan media utama dalam pembelajaran, yaitu aplikasi Whatsapp.

\section{E. Kesimpulan}

Berdasarkan pembahasan hasil penelitian yang telah dilakukan peneliti dalam Pemanfaatan aplikasi whatsapp sebagai media pembelajaran berbasis distancing learning pada kelas E MPBA UIN Malang disimpulkan bahwa sebagai sarana pembelajaran ini termasuk dalam kategori efektif atau maksimal. Hasil penelitian berimplikasi bagi penggunaan whatsapp sebagai media pembelajaran, bahwa sebenarnya masih bisa ditingkatkan lagi sangat efektif jika dilakukan evaluasi yang kembali pada pengguna itu sendiri sebagai yang memanfaatkan. Karena komunikasi merupakan kebutuhan manusia, serta dari waktu ke waktu media komunikasi terus mengalami perubahan sehingga saat ini media yang popular adalah sosial media berbasis online, salah satunya aplikasi Whatsapp, serta menstimulasi pengguna sehingga pengguna menjadi komunikatif, pengguna berpartisipasi aktif dalam diskusi materi pembelajaran. Berusaha mendapatkan kepuasan dengan turut berdiskusi dan bertukar informasi. Jika belum merasa puas dengan hasil diskusi maupun tanggapan atas pertanyaan dan pernyataan maka pengguna harus terus bertanya maupun memberi tanggapan baru atas penyataan yang didapat hingga terpenuhinya kepuasan yang diharapkan.

\section{Daftar Rujukan}

Anitah, Sri. Media pembelajaran. Surakarta: UPT UNS Press Universitas Sebelas Maret, 2008.

Kompas. "Whatsapp Tembus 2 Miliar Pengguna." Diakses 3 Juli 2021. https://tekno.kompas.com/read/2020/02/13/18190017/whatsapp-tembus-2-miliarpengguna. 
Lestari, Wiji. "Pemanfaatan Whatsapp Sebagai Media Pembelajaran Dalam Jaringan Masa Pandemi Covid-19 Di Kelas Vi Sekolah Dasar.” Skripsi, Universitas Jambi, 2021.

Liputan6.com. "Pengguna Internet Dunia Tembus 4,66 Miliar, Rata-Rata Online di Smartphone." liputan6.com, $28 \quad$ Januari 2021. https://www.liputan6.com/tekno/read/4469008/pengguna-internet-dunia-tembus-466miliar-rata-rata-online-di-smartphone.

LPMP Jatim. “Whatsapp Paling Diminati untuk Pembelajaran Online." Diakses 3 Juli 2021. https://lpmpjatim.kemdikbud.go.id/site/detailpost/whatsapp-paling-diminati-untukpembelajaran-online.

Munir. Kurikulum Berbasis Teknologi Informasi dan Komunikasi. Bandung: Alfabeta, t.t.

Prajana, Andika. "Pemanfaatan aplikasi whatsapp untuk media pembelajaran dalam lingkungan uin ar-raniry Banda Aceh." Cyberspace: Jurnal Pendidikan Teknologi Informasi 1, no. 2 (2017): 122-33.

Rusman, Deni Kurniawan, dan Cepi Riyana. "Pembelajaran Berbasis Teknologi Informasi dan Komunikasi." Bandung: Rajawali Pers, 2011.

Sanjaya, Ridwan. Refleksi Pembelajaran Daring di Masa Darurat. Semarang: SCU Knowledge Media, 2020.

Suryani, Rani. "Fungsi Whatsapp Grup Shalihah Cabang Bandar Lampung Sebagai Pengembangan Media Dakwah Dalam Membentuk Akhlakul Karimah." UIN Raden Intan Lampung, 2017. 